\title{
Comparison of Quality Control Parameters of Leaf and Stem of Phyla nodiflora L. Greene (Verbenaceae)
}

\author{
Bhoomi Trivedi, Savan Donga, Jyoti Pande and Sumitra Chanda* \\ Phytochemical, Pharmacological and Microbiological Laboratory, Department of \\ Biosciences (UGC-CAS), Saurashtra University, Rajkot-360005, India \\ *Corresponding author
}

\section{A B S T R A C T}

\section{Keywords}

Phyla nodiflora,

Verbenaceae,

Pharmacognostic

studies, Powder

microscopy, Leaf,

Stem, Quality

control parameters

Article Info

Accepted:

20 April 2018

Available Online:

10 May 2018
Phyla nodiflora L. Greene (Verbenaceae) is a medicinal plant commonly known as Ratoliya in Gujarati and Bhujokra in Hindi. Traditionally it is used to cure many diseases like diarrhoea, ulcers, asthma, bronchitis, knee joint pain, gonorrhoea and also there are many reported pharmacological activities like antibacterial, antifungal, antiinflammation, antiulcer, antidiuretic, etc. Thus, it is very essential to lay down quality control parameters so that the therapeutic efficacy of the plant can be maintained. In order to achieve this, in the present work, Phyla nodiflora leaf and stem were evaluated for their physicochemical, phytochemical and pharmacognostic parameters. For phytochemical analysis, different phytoconstituents like saponins, tannins, glycosides, phenols, triterpenes, flavonoids, steroids, etc. were evaluated. For physicochemical analysis, different ash values, extractive values and loss on drying was determined following all standard procedures. Both leaf and stem were rich in phenols, flavonoids and alkaloids; however, leaf had steroids and stem had saponins in maximum amount. The ash values were more in leaf than in stem while loss on drying was almost same (>10\%) in both the parts. Likewise, extractive value was maximum in methanol and minimum in petroleum ether. The diagnostic characters laid down in this study will be helpful for its correct identification and ensure its purity. They are the most simple, easy and cheapest quality control parameters.

\section{Introduction}

Herbal drugs referred as plant based materials, involves the use of whole plant or parts of plant to treat injuries or illness (Edeoga et al., 2005). Medicinal plants occupy a significant position in community because they play a vital role in human health. The medicinal value of the plants lies in some chemical substances that cause a definite action on human body. Medicinal plants are widely used by the traditional medical practitioners for counteracting various diseases in their routine practice. Natural products from plants have been the basis of the treatment of human disease. Today $80 \%$ of population of developing countries still rely on traditional medicine based on plant species for their primary health. Herbal medicines are currently in demand and their popularity is increasing 
day by day (Verma and Singh, 2008). Herbal drugs are commonly used throughout the world because of lower side effects, easy availability, low cost and its effectiveness (Nasri and Shirzad, 2013).

Since many years, humans have relied on nature for their basic needs for the production of food-stuffs, shelters, clothing means of transportation, fertilizers, flavours, fragrances, and medicines. Plants have formed traditional medicine systems that have been in existence for thousands of years and continue to provide mankind with new remedies (Gurib-Fakim, 2006). The search for new pharmacologically active agents obtained by screening of plant extracts has led to the discovery of many clinically useful drugs that play a major role in the treatment of human diseases (Shu, 1998). Plants have many therapeutic activities like antibacterial (Kumar et al, 2014; Rakholiya et al., 2014a; Donga et al., 2017a), antioxidant (Rakholiya et al., 2014b; Donga et al., 2017b), anti-inflammatory (Zhen et al., 2016), diuretic (Chen et al., 2014), hepatoprotective (Muthaiyan et al.,2015), etc. Despite taxonomical classification, herbal drugs can be classified according to their morphological character. For e.g. seed drug shows antioxidant activity (Hussain et al., 2016), leaf drug shows - antidiabetic activity (Arumugam et al., 2008), bark drug shows- antibacterial activity (Muthkar et al., 2006) flower drug shows - anti-inflammatory activity (Balkan et al., 2018).

Phyla nodiflora L. Greene is an important member of the family Verbenaceae. This family includes 34 genera. Plants from Verbenaceae family are well known for their use in traditional medicinal system of various countries. Phyla is used as the traditional medicine for the treatment of various skin diseases and is used as folk cosmetics among the tribal communities of Pakistan (Abbasi et al., 2010). Some of the reported pharmacological activities of Phyla nodiflora are given in Figure 1. Medicinal plants are in use since ages however they are not becoming as popular as they deserve mainly because there are no stringent quality control methods for herbal drugs. The importance of herbal medicine is questioned and quite often they are prone to adulteration and substitution intentionally or unintentionally. Thus, quality control and standardization is essential at each step for e.g. Raw material standardization, manufacture process standardization and standardization of finished product. This will ensure the quality, safety and efficacy of herbal drugs.

Considering the above, in the present work, an attempt has been done to lay down quality control parameters of Phyla nodiflora. It involves pharmacognostic standardization. The pharmacognostic standardization parameters which are generally done are organoleptic characters, macroscopic study, microscopic study, physicochemical analysis, phytochemical analysis, fluorescence analysis (Chanda, 2014). The parameters evaluated are given in Figure 2.

\section{Materials and Methods}

\section{Plant collection}

Plant Phyla nodiflora (L.) Greene was collected in August, 2017 from Porbandar, Gujarat, India. The plant parts leaf and stem were separated, washed thoroughly under tap water, Shade dried and homogenized to fine powder and stored in closed container for further studies.

\section{Pharmacognostic study}

\section{Macroscopic studies}

Pharmacognostic study was done by organoleptic evaluation. The morphological 
features of different parts of the plant were observed under magnifying lens. Macroscopic characters were studied using standard methods (Khandelwal, 2008). Photographs at different magnifications were taken by using digital camera.

\section{Microscopic studies}

Microscopic studies were carried out by preparing thin sections of different part of different plants. The thin sections were further washed with water, stained with safranin, fast green and mounted in glycerine for observation and confirm its lignifications (10x, 40x). The powder microscopic studies were also carried out and the specific diagnostic characteristic features were recorded (Tyler et al., 1977).

\section{Qualitative phytochemical analysis}

The qualitative phytochemical analysis of crude powder of $P$. nodiflora leaf and stem was carried out to identify different phytoconstituents (Harbone, 1998). The phytoconstituents analysed were alkaloids, flavonoids, phenols, saponins, tannins, cardiac glycosides, steroids, phlobatannins, triterpenes, anthocyanins, etc. The presence of specific phytochemicals was indicated with (+) sign and the absence of phytochemicals was indicated with (-) sign. The procedure followed is given in Table 1.

\section{Physicochemical analysis}

The physicochemical parameters like loss on drying, total ash, acid-insoluble ash, watersoluble ash, sulphated ash, nitrated ash, carbonated ash and extractive values were determined as per WHO guidelines (WHO, 1998). The solvents used were petroleum ether (PE), toluene (TO), ethyl acetate (EA), methanol (ME) and water (AQ). The details of the procedure are described below:

\section{Loss on drying}

Two grams of dried plant powder was taken in a silica crucible. The sample was dried in an oven at $100^{\circ} \mathrm{C}-110^{\circ} \mathrm{C}$. It was dried until constant weight was obtained. The weight after drying was noted and loss on drying was calculated in $\mathrm{mg} / \mathrm{g}$. The percentage was calculated on the basis sample taken initially.

\section{Determination of total ash}

Two grams of dried plant powder was taken in a silica crucible. Then it was placed in a Muffle furnace at $500^{\circ} \mathrm{C}$ for $5 \mathrm{~h}$ to remove all the carbon. It was allowed to cool and weighed. Total ash was white in colour which indicated absence of carbon and it was calculated as $\mathrm{mg} / \mathrm{g}$ of air dried plant material (WHO, 2002).

\section{Determination of acid insoluble ash}

$25 \mathrm{ml}$ of hydrochloric acid $(70 \mathrm{~g} / \mathrm{L})$ was added to the crucible containing total ash. It was covered with a watch-glass and heated gently for $5 \mathrm{~min}$ to boil. The watch-glass was rinsed with $5 \mathrm{ml}$ of hot water and this liquid was added to the crucible. The insoluble matter was collected on an ash less filter paper and it was washed with hot water until the filtrate was neutral. The filter paper containing the insoluble matter was transferred to the original crucible; then it was put in Muffle furnace at $500^{\circ} \mathrm{C}$ for $2 \mathrm{~h}$. It was allowed to cool and then weighed. Acid insoluble ash was calculated as $\mathrm{mg} / \mathrm{g}$ of air dried material.

\section{Determination of water soluble ash}

$25 \mathrm{ml}$ of distilled water was added to the crucible containing total ash and boiled for 5 min. The insoluble matter was collected on an ash less filter paper; then it was washed with hot water and heated in a crucible for $15 \mathrm{~min}$. The weight of insoluble matter was subtracted 
from the weight of total ash. The content of water soluble ash was calculated as $\mathrm{mg} / \mathrm{g}$ of air dried material.

\section{Determination of sulphated ash}

Total ash was determined as described above. $2 \mathrm{ml}$ of $0.1 \mathrm{~N} \mathrm{H}_{2} \mathrm{SO}_{4}$ was added to the crucible containing total ash and incubated at room temperature for $10 \mathrm{~min}$; then it was put in a Muffle furnace at $500^{\circ} \mathrm{C}$ for $5 \mathrm{~h}$. It was allowed to cool and then weighed. The content of sulphated ash was calculated as $\mathrm{mg} / \mathrm{g}$ air dried material.

\section{Determination of nitrated ash}

Total ash was determined as described above. $2 \mathrm{ml}$ of $0.1 \mathrm{~N} \mathrm{HNO}_{3}$ was added to the crucible containing total ash and incubated at room temperature for 10 minutes. Then it was put in Muffle furnace at $500^{\circ} \mathrm{C}$ for $5 \mathrm{~h}$. It was allowed to cool and then weighed. The content of nitrated ash was calculated as $\mathrm{mg} / \mathrm{g}$ air dried material.

\section{Determination of carbonated ash}

Total ash was determined as described above. $2 \mathrm{ml} 0.1 \mathrm{~N} \mathrm{Na}_{2} \mathrm{CO}_{3}$ was added to the crucible containing total ash and incubated at room temperature for 10 minutes, then it was put in Muffle furnace at $500^{\circ} \mathrm{C}$ for $5 \mathrm{~h}$. It was allowed to cool and then weighed. The content of carbonated ash was calculated as $\mathrm{mg} / \mathrm{g}$ air dried material.

\section{Extractive values}

The extractive value of dried plant powder was evaluated by extracting the dry powder in solvents of different polarity. The solvents used were petroleum ether (PE), toluene (TO), ethyl acetate (EA), methanol (ME) and water (AQ). The procedure followed was as described below. Five grams of dried plant powder was taken in $250 \mathrm{ml}$ conical flask and $100 \mathrm{ml}$ of different solvents were added individually and they were placed on a rotary shaker at $120 \mathrm{rpm}$ for $24 \mathrm{~h}$. Then it was filtered by eight layers of muslin cloth and the filtrate was centrifuged at $5000 \mathrm{rpm}$ for 15 minutes. The solvent was evaporated to dryness and dried crude extract was stored in air tight bottles at $4^{0} \mathrm{C}$. It was further used in different analysis.

\section{Fluorescence analysis}

Fluorescence study of crude powder of $P$. nodiflora leaf and stem was performed as per kokaski et al., (1958). A small quantity of the crude powder of different plants was placed on a grease free clean microscopic slide and 12 drops of freshly prepared various reagent solutions were added, mixed by gentle tilting of the slide. The slides were placed inside the UV chamber and observed in visible light, short (wave length $254 \mathrm{~nm}$ ) and long (wave length $365 \mathrm{~nm}$ ) ultra violet radiations. The colors observed by applications of different reagents in different wave lengths were recorded.

\section{Results and Discussion}

\section{Organoleptic and macroscopic characteristics}

Organoleptic and macroscopic characteristics of $P$. nodiflora leaf and stem are given in Table 2 and Figure 3. The leaf was simple, opposite decussate phyllotaxy, spathulate shape, lobed margin, retuse apex, symmetrical leaf base, scabrous appearance, reticulate venation, odour was characteristic and taste was bitter. The average leaf size was $2.6-3 \mathrm{~cm}$ in length and $1-1.5 \mathrm{~cm}$ in width (Table 2 and Fig. 3). The stem was green, herbaceous, prostrate trailing, cylindrical, up to $36-40 \mathrm{~cm}$ in height and 0.2-0.4 in thickness, odour was characteristic, taste was bitter and outer 
surface was rough (Table 2).

\section{Microscopic characteristics}

The transverse section of $P$. nodiflora is shown in Figure 4. The petiole was kidney shaped. The upper and lower epidermis was single layered (Fig. 4a). Hypodermis was 8-9 celled with collenchymataous tissue. The upper layer was made up of 2-3 parenchymatous cells; vascular bundles were 'arc' shape, the size of the vascular bundles varied from centre to leaf margin that is large too small. They were centripetal arranged i.e. xylem surrounded by the phloem (Fig. 4b). The transverse section of $P$. nodiflora leaf is shown in Figure 4. The leaf lamina was dorsiventral in nature. The upper epidermis and lower epidermis was single layered. The palisade tissue was single layered on the upper surface and was covered with thick cuticle (Fig. 4c). The mesophyll was small 5-7 layered, the ground tissue was made up of parenchymatous cells, and spongy parenchyma cells were present on the lower surface of epidermis (Fig. 4d). T.S. passing through the mid rib region showed vascular bundles towards the ventral surface. The vascular bundles were centrally located conjoint collateral and were surrounded by parenchymatous cells (Fig. 4e). The diacytic stomata were present in lower epidermis; the stomata were surrounded by small subsidiary cells, where as the guard cells were comparatively small in size and each stoma were surrounded by 2 subsidiary cells (Fig. 4f).

The transverse section of $P$. nodiflora stem is shown in Figure 5. The epidermis was single layered with cubical cells surrounded by cuticle (Fig. 5a). The cortex consisted of 4-6 layers, vascular bundles were surrounded by polygonal lignified parenchyma and chollenchyma cells (Fig. 5b).Vascular bundles consisted of secondary phloem with sieve tubes, companion cells and phloem paranchyma; secondary xylem consisted of metaxylem, lignified trachea, tracheids, few vessels and xylem fibre. Fibers were pitted elongated and moderately thickened (Fig. 5c). Pith was very large and consisted of thin walled sclerenchymatous cells (Fig. 5d).

\section{Powder microscopy}

The crude powder of $P$. nodiflora leaf and stem was dark green in colour, fine, odour characteristic and was bitter taste. The powder microscopy characteristics of leaf and stem are shown in Figures 6-7. The specific characteristics determined from the powder study of leaf under microscopic investigation showed unicellular trichomes, diacytic stomata, annular vessles, spiral vessles, etc. The specific characteristics determined from the powder study of stem showed border pitted vessels, annular vessels, spiral vessels, parenchymatous tissue, etc.

\section{Phytochemical analysis}

The qualitative phytochemical analysis of crude powder of $P$. nodiflora leaf and stem are given in Table 3. In leaf, alkaloids, flavonoids, phenols and steroids were present in maximum amount followed by quinones; tannins, saponins, cardiac glycosides and coumarins were present in trace amount. Phlobatanins, triterpenes, anthocyanins and Leucoanthocyanins were absent. In stem, alkaloids and flavonoids were present in maximum amount followed by tannins, saponins, phenols and coumarins. Quinones and steroids were present in trace amount while leucoanthocyanin, cardiac glycosides, triterpenes, anthocyanin and phlobatanins were absent

\section{Physicochemical analysis}

The physicochemical parameters of the crude powder of $P$. nodiflora leaf and stem of are given in Figure 8. The moisture content of leaf and stem was 8.25 and $9 \%$ respectively. The 
ash values of leaf and stem are given in Figure 8. The total ash of leaf was $27.41 \%$, water soluble ash was $6.33 \%$ and acid insoluble ash was $7 \%$; while for stem they were $12.33 \%$, $4.33 \%$ and $2.16 \%$ respectively. The sulphated ash, nitrated ash and carbonated ash of leaf were $31.33 \%, 27 \%$ and $27.5 \%$ respectively; for stem they were $14.33 \%, 18.66 \%, 12.16 \%$ respectively. The ash values were more in leaf than in stem.

Extractive values of leaf and stem in different solvents is given in Figure 9. The extractive values for leaf ranged from $0.38 \%$ to $7.85 \%$ for polar and non-polar solvents while the same for stem ranged from $0.28 \%$ to $19.43 \%$. In both leaf and stem, maximum extractive value was in ME solvent and minimum in PE solvent. The water soluble extractive value for leaf and stem were $13.58 \%$ and $12.99 \%$ respectively. The non-polar and semi polar solvents had low extractive values while polar solvent methanol and water had maximum extractive values. In ME solvent, the extractive value in stem was considerably more than in leaf. On the other hand, in aqueous extract, the extractive values of leaf and stem were almost same.

\section{Fluorescence analysis}

The fluorescence analysis of crude powder of $P$. nodiflora leaf and stem are shown in Tables 4 and 5. The fluorescence characters of medicinal plants play an important role in the determination of quality and purity of the drug material. In the present study dried powder of medicinal plant $P$. nodiflora was treated with a number of different reagents, which showed characteristic fluorescence at $254 \mathrm{~nm}$ and 365 $\mathrm{nm}$ wave length. The plant powder of $P$. nodiflora showed different colors at both wave lengths. The colours observed were dark green, green, brown, reddish brown and black for leaf; and dark green, light green, green, yellowish green, whitish green, black, reddish brown and brown for stem.

Table.2 Organoleptic features of $P$. nodiflora leaf and stem

\begin{tabular}{|c|c|c|}
\hline Characters & Observation & Observation \\
\hline Part & Leaf & Stem \\
\hline Arrangement & Opposite & Prostrate trailing \\
\hline Size & $\begin{array}{l}2.6-3 \mathrm{~cm} \text { long and } 1-1.5 \mathrm{~cm} \\
\text { wide }\end{array}$ & $\begin{array}{l}36-40 \mathrm{~cm} \text { long and } 0.2- \\
0.4 \mathrm{~cm} \text { wide }\end{array}$ \\
\hline Shape & Spathulate & Cylindrical \\
\hline Color & Green & Green \\
\hline Odour & Characteristic & Characteristic \\
\hline Taste & Bitter & Bitter \\
\hline Appearance & Rough & Rough \\
\hline Margin & Lobed & - \\
\hline Apex & Retuse & - \\
\hline Base & Symmetrical & - \\
\hline Petiole & Short & - \\
\hline Texture & Smooth & Rough \\
\hline Venation & Reticulate & - \\
\hline Outer surface & Rough & Rough \\
\hline
\end{tabular}


Table.1 Procedure followed for the estimation various phytochemicals

\begin{tabular}{|c|c|c|c|}
\hline No. & Phytochemicals & Test & Observation \\
\hline \multirow{3}{*}{1} & \multirow{3}{*}{ Alkaloids } & $\begin{array}{l}\text { Add crude powder of leaf and stem to } \\
2 \mathrm{~N} \mathrm{HCl} \text { and mixture was filtrated. } \\
\text { 1) The filtrate was treated with few } \\
\text { drops of Dragondroff's reagent }\end{array}$ & $\begin{array}{l}\text { Formation of orange } \\
\text { precipitate indicated the } \\
\text { presence of alkaloids }\end{array}$ \\
\hline & & $\begin{array}{l}\text { 2) The filtrate was treated with few } \\
\text { drops of Mayer's reagent }\end{array}$ & $\begin{array}{l}\text { Formation of Cream } \\
\text { precipitate indicated the } \\
\text { presence of alkaloids }\end{array}$ \\
\hline & & $\begin{array}{l}\text { 3) The filtrate was treated with few } \\
\text { drops of Wagner's reagent }\end{array}$ & $\begin{array}{l}\text { Formation of brown } \\
\text { precipitate indicated the } \\
\text { presence of alkaloids }\end{array}$ \\
\hline 2 & Phenols & $\begin{array}{l}\text { The crude powder of leaf and stem was } \\
\text { dissolved in distilled water. It was } \\
\text { filtered the filtrate was treated with a } \\
\text { few drops of } 5 \% \mathrm{FeCl}_{3} \text { solution }\end{array}$ & $\begin{array}{l}\text { Formation of deep blue } \\
\text { colour indicated the } \\
\text { presence of phenols }\end{array}$ \\
\hline 3 & Flavonoids & $\begin{array}{l}\text { The crude powder of leaf and stem was } \\
\text { dissolved in distilled water. It was } \\
\text { filtered the filtrate was treated with a } \\
\text { few drops of diluted } \mathrm{NaOH} \text {, again add } \\
\text { few drops of diluted } \mathrm{HCl}\end{array}$ & $\begin{array}{l}\text { Formation of yellow } \\
\text { orange colour to } \\
\text { colourless indicated the } \\
\text { presence of flavonoids }\end{array}$ \\
\hline 4 & $\begin{array}{l}\text { Saponins } \\
\text { (Frothing test) }\end{array}$ & $\begin{array}{l}\text { The crude powder of leaf and stem was } \\
\text { vigorously shaken with distilled water } \\
\text { and allowed to stand for } 10 \text { min }\end{array}$ & $\begin{array}{l}\text { Stable formation of froth } \\
\text { for } 1 \text { min indicated } \\
\text { presence of saponins }\end{array}$ \\
\hline 5 & $\begin{array}{l}\text { Tannins } \\
\left(\mathrm{FeCl}_{3} \text { test }\right)\end{array}$ & $\begin{array}{l}\text { The crude powder of leaf and stem was } \\
\text { dissolved in distilled water. It was } \\
\text { filtered and the filtrate was treated with } \\
\text { alcoholic ferric chloride }\left(\mathrm{FeCl}_{3}\right) \text { reagent }\end{array}$ & $\begin{array}{l}\text { Formation of blue colour } \\
\text { indicated the presence of } \\
\text { tannins }\end{array}$ \\
\hline 6 & $\begin{array}{l}\text { (Liebennann - } \\
\text { Burchard test) }\end{array}$ & $\begin{array}{l}\text { The crude powder of leaf and stem was } \\
\text { dissolved in chloroform. It was filtered } \\
\text { and the filtered chloroform extract was } \\
\text { treated with acetic anhydride and a few } \\
\text { drops of concentrated } \mathrm{H}_{2} \mathrm{SO}_{4}\end{array}$ & $\begin{array}{l}\text { Formation of blue green } \\
\text { ring indicated the } \\
\text { presence of steroids }\end{array}$ \\
\hline
\end{tabular}




\begin{tabular}{|c|c|c|c|}
\hline 7 & Phlobatanins & $\begin{array}{l}\text { The crude powder of leaf and stem was } \\
\text { boiled with } 1 \% \text { aqueous } \mathrm{HCl}\end{array}$ & $\begin{array}{l}\text { Formation of red } \\
\text { precipitate indicated the } \\
\text { presence of phlobatannins }\end{array}$ \\
\hline 8 & Anthocyanins & $\begin{array}{l}\text { The crude powder of leaf and stem was } \\
\text { dissolved in methanol. It was filtered } \\
\text { and the filtered methanolic extract was } \\
\text { treated with } 2.0 \mathrm{ml} \mathrm{NaOH}(1 \mathrm{~N})\end{array}$ & $\begin{array}{l}\text { The colour of the solution } \\
\text { changed to blue indicated } \\
\text { the presence of } \\
\text { anthocyanins }\end{array}$ \\
\hline 9 & Triterpenes & $\begin{array}{l}\text { The crude powder of leaf and stem was } \\
\text { dissolved in chloroform. It was filtered } \\
\text { and the filtered chloroform extract was } \\
\text { treated with concentrated } \mathrm{H}_{2} \mathrm{SO}_{4}\end{array}$ & $\begin{array}{l}\text { Formation of reddish } \\
\text { brown ring indicated the } \\
\text { presence of triterpens }\end{array}$ \\
\hline 10 & $\begin{array}{l}\text { Cardiac Glycosides } \\
\text { (Keller - Kiliani test) }\end{array}$ & $\begin{array}{l}\text { The crude powder of leaf and stem was } \\
\text { dissolved in distilled water. It was } \\
\text { filtered and the filtered aqueous extract } \\
\text { was treated with } 1.0 \mathrm{ml} \text { mixture of } 5 \% \\
\mathrm{FeCl}_{3} \text { and glacial acetic acid }(1.99 \mathrm{~V} / \mathrm{V}) \text {. } \\
\text { To this solution, few drops of } \\
\text { concentrated } \mathrm{H}_{2} \mathrm{SO}_{4} \text { was added }\end{array}$ & $\begin{array}{l}\text { Appearance of greenish } \\
\text { blue colour within few } \\
\text { minutes indicated the } \\
\text { presence of cardiac } \\
\text { glycosides }\end{array}$ \\
\hline 11 & Coumarins & $\begin{array}{l}\text { The crude powder of leaf and stem was } \\
\text { dissolved in distilled water. It was } \\
\text { filtered and the filtered aqueous extract } \\
\text { was treated with } 10 \% \mathrm{NaOH}\end{array}$ & $\begin{array}{l}\text { Formation of yellow } \\
\text { colour of the solution } \\
\text { indicated the presence of } \\
\text { coumarins }\end{array}$ \\
\hline 12 & Leucoanthocyanins & $\begin{array}{l}\text { The crude powder of leaf and stem was } \\
\text { dissolved in distilled water. It was } \\
\text { filtered and the filtered aqueous extract } \\
\text { was treated with isoamyl alcohol in } \\
\text { equal proportion. }\end{array}$ & $\begin{array}{l}\text { Appearance of red colour } \\
\text { in upper layer indicated } \\
\text { the presence of } \\
\text { leucoanthocyanins }\end{array}$ \\
\hline 13 & Quinones & $\begin{array}{l}\text { The crude powder of leaf and stem was } \\
\text { dissolved in methanol. It was filtered } \\
\text { and the filtered methanolic extract was } \\
\text { treated with } \mathrm{HCl}\end{array}$ & $\begin{array}{l}\text { Formation of yellow } \\
\text { precipitation indicated the } \\
\text { presence of quinones }\end{array}$ \\
\hline
\end{tabular}

Table.3 Qualitative phytochemical analysis of $P$. nodiflora leaf and stem

\begin{tabular}{|l|l|l|l|}
\hline No. & Phytochemicals & Leaf & Stem \\
\hline 1 & Dragondroff's reagent (alkaloids) & +++ & +++ \\
\hline 2 & Mayers test (alkaloids) & + & + \\
\hline
\end{tabular}




\begin{tabular}{|l|l|l|l|}
\hline 3 & Wagner,s test (alkaloids) & ++ & ++ \\
\hline 4 & Alkaline reagent (flavonoids) & +++ & +++ \\
\hline 5 & Ferric chloride test (tannins) & + & ++ \\
\hline 6 & Phlobatanins & - & - \\
\hline 7 & Frothing test (saponins) & + & ++ \\
\hline 8 & Liebennann -Burchard test (steroids) & +++ & + \\
\hline 9 & Keller - Kiliani test (cardiac glycosides) & + & - \\
\hline 10 & Salkowski's test (triterpenes) & - & - \\
\hline 11 & Anthocyanins & - & - \\
\hline 12 & $\mathbf{5} \%$ Ferric chloride test (phenols) & +++ & ++ \\
\hline 13 & Coumarins & + & ++ \\
\hline 14 & Leucoanthocyanins & - & - \\
\hline 15 & Quinones & ++ & + \\
\hline
\end{tabular}

Note: (+++) more amount, (++) moderate amount, (+) less amount, (-) absent

Table.4 Fluorescence analysis of $P$. nodiflora leaf

\begin{tabular}{|c|c|c|c|c|}
\hline No. & Treatment & $\begin{array}{l}\text { Under visible } \\
\text { light }\end{array}$ & $\begin{array}{l}\text { Under UV light } \\
\text { short wave } \\
\text { length }(254 \mathrm{~nm})\end{array}$ & $\begin{array}{l}\text { Under UV light } \\
\text { long wave } \\
\text { length }(365 \mathrm{~nm})\end{array}$ \\
\hline 1 & 1N NaOH (Aq) & Green & Black & Green \\
\hline 2 & 1N NaOH (Alc) & Green & Green & Brown \\
\hline 3 & Ammonia & Green & Black & Dark green \\
\hline 4 & Petroleum ether & Green & Black & Dark green \\
\hline 5 & $50 \% \mathrm{HCl}$ & Dark green & Black & Black \\
\hline 6 & $50 \% \mathrm{H}_{2} \mathrm{SO}_{4}$ & Dark green & Black & Brown \\
\hline 7 & Ethyl-acetate & Dark green & Black & Green \\
\hline 8 & Ethyl-alcohol & Green & Black & Green \\
\hline 9 & Methanol & Green & Black & Green \\
\hline$\overline{10}$ & $50 \%$ КОН & Green & Black & Black \\
\hline 11 & $50 \% \mathrm{HNO}_{3}$ & Reddish brown & Black & Black \\
\hline 12 & Acetic acid & Green & Black & Green \\
\hline 13 & Iodine in water & Green & Black & Dark green \\
\hline 14 & $\mathrm{FeCl}_{3}$ & Dark green & Black & Black \\
\hline
\end{tabular}

Table.5 Fluorescence analysis of $P$. nodiflora stem 


\begin{tabular}{|c|c|c|c|c|}
\hline No. & Treatment & $\begin{array}{l}\text { Under visible } \\
\text { light }\end{array}$ & $\begin{array}{l}\text { Under UV light } \\
\text { short wave } \\
\text { length }(254 \mathrm{~nm})\end{array}$ & $\begin{array}{l}\text { Under UV light } \\
\text { long wave length } \\
(365 \mathrm{~nm})\end{array}$ \\
\hline 1 & $1 \mathrm{~N} \mathrm{NaOH}(\mathrm{Aq})$ & Brown & Black & Brown \\
\hline 2 & 1N NaOH (Alc) & Brown & Green & Green \\
\hline 3 & Ammonia & Brown & Black & Dark green \\
\hline 4 & Petroleum ether & Brown & Brown & Light green \\
\hline 5 & $50 \% \mathrm{HCl}$ & Light green & Black & Brown \\
\hline 6 & $50 \% \mathrm{H}_{2} \mathrm{SO}_{4}$ & Light green & Black & Greenish brown \\
\hline 7 & Ethyl-acetate & Light green & Black & Whitish green \\
\hline 8 & Ethyl-alcohol & Green & Black & Whitish green \\
\hline 9 & Methanol & Yellowish green & Black & Whitish green \\
\hline 10 & $50 \%$ КОН & Green & Black & Black \\
\hline 11 & $50 \% \mathrm{HNO}_{3}$ & Reddish brown & Black & Black \\
\hline 12 & Acetic acid & Whitish green & Black & Whitish green \\
\hline 13 & Iodine in water & Whitish green & Black & Dark green \\
\hline 14 & $\mathrm{FeCl}_{3}$ & Dark green & Black & Black \\
\hline
\end{tabular}

Fig.1 Different reported activities of $P$. nodiflora L. Greene

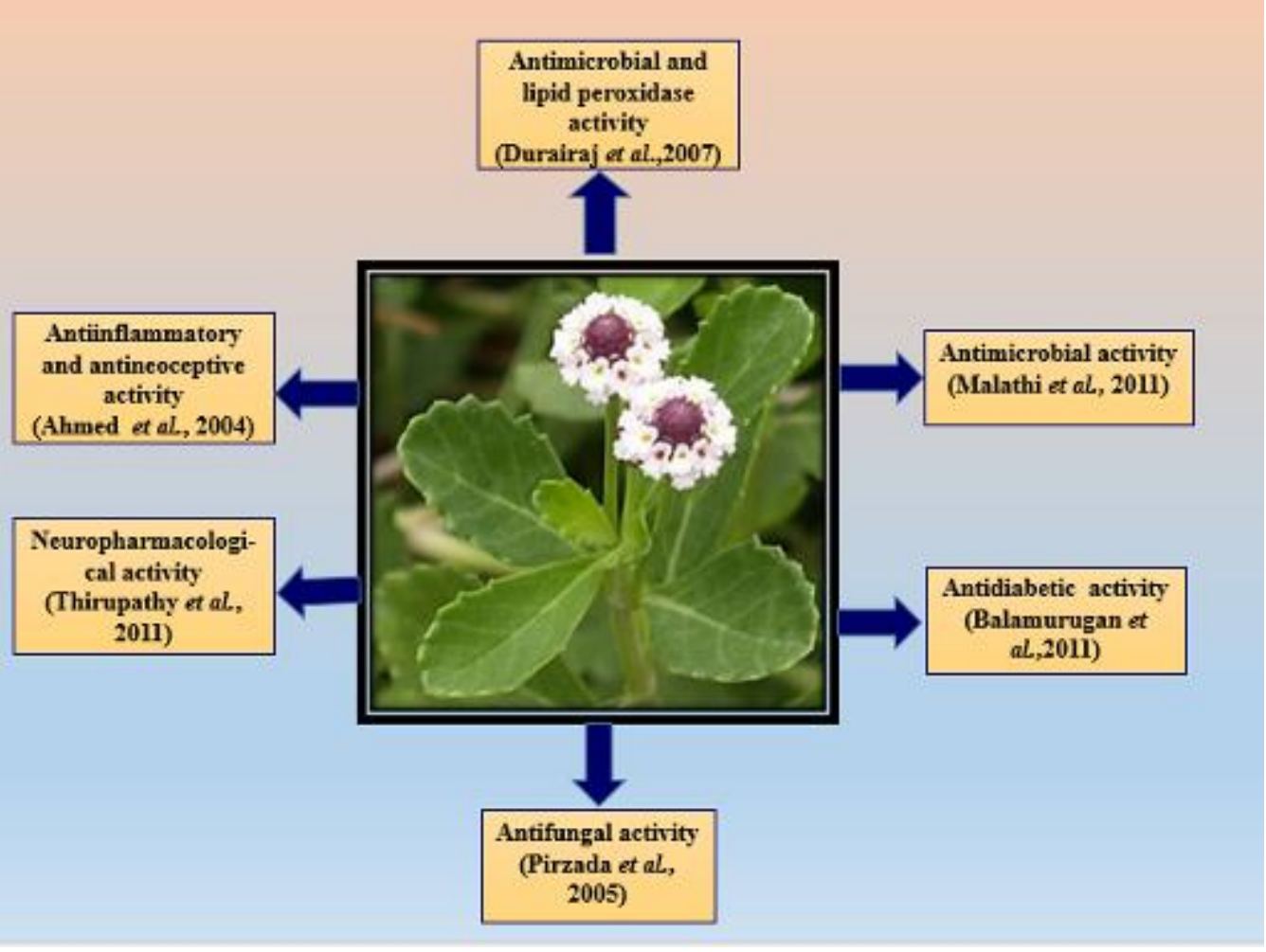

Fig.3 Macroscopic study of $P$. nodiflora

\section{a) Habit}




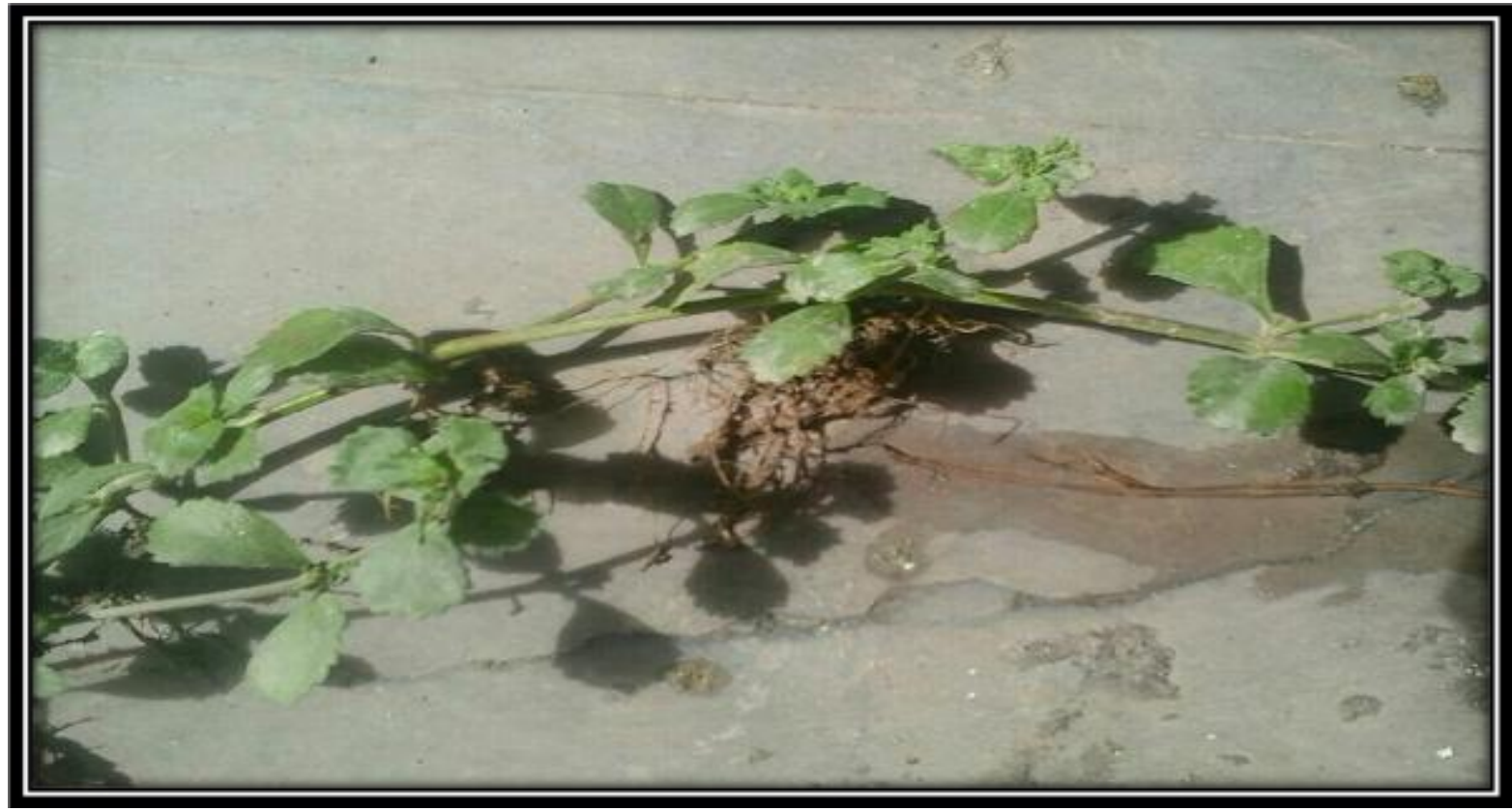

b) Macroscopic study of leaf

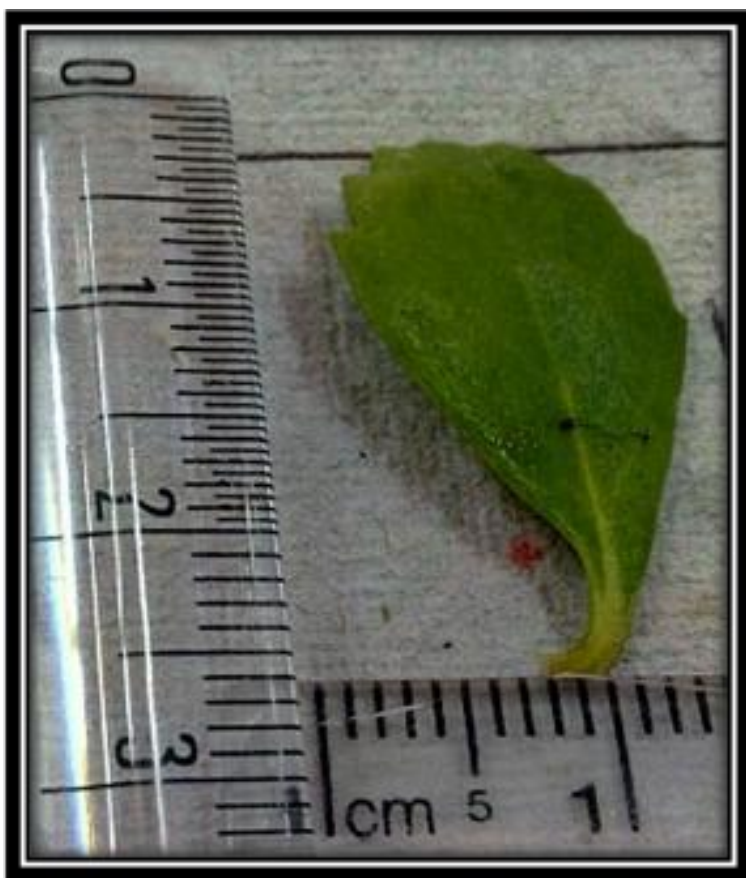

c) Macroscopic study of stem

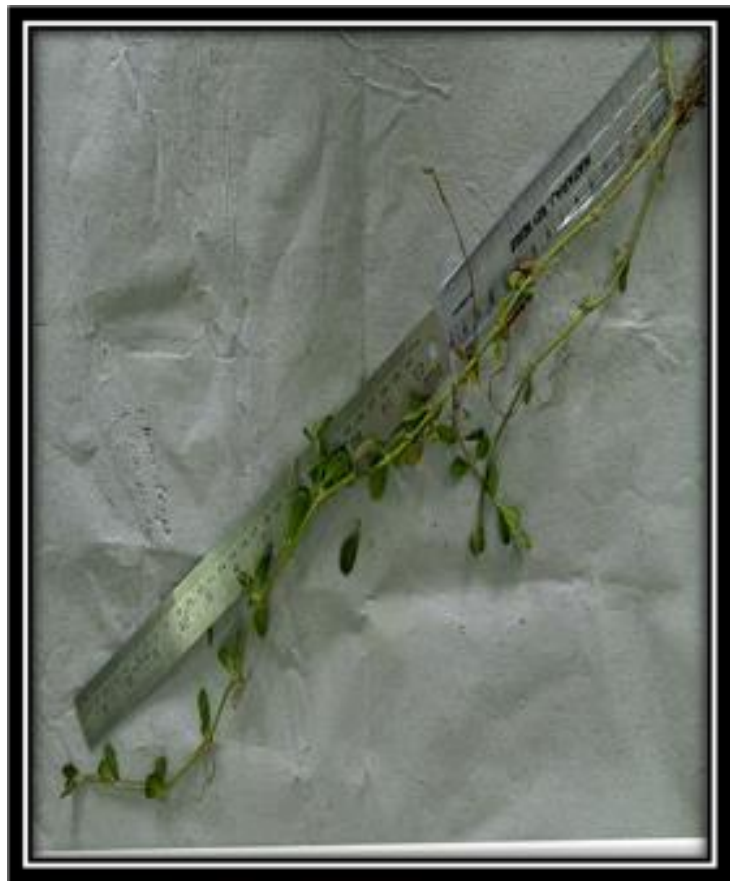

Fig.4 Microscopic study of leaf of $P$. nodiflora 

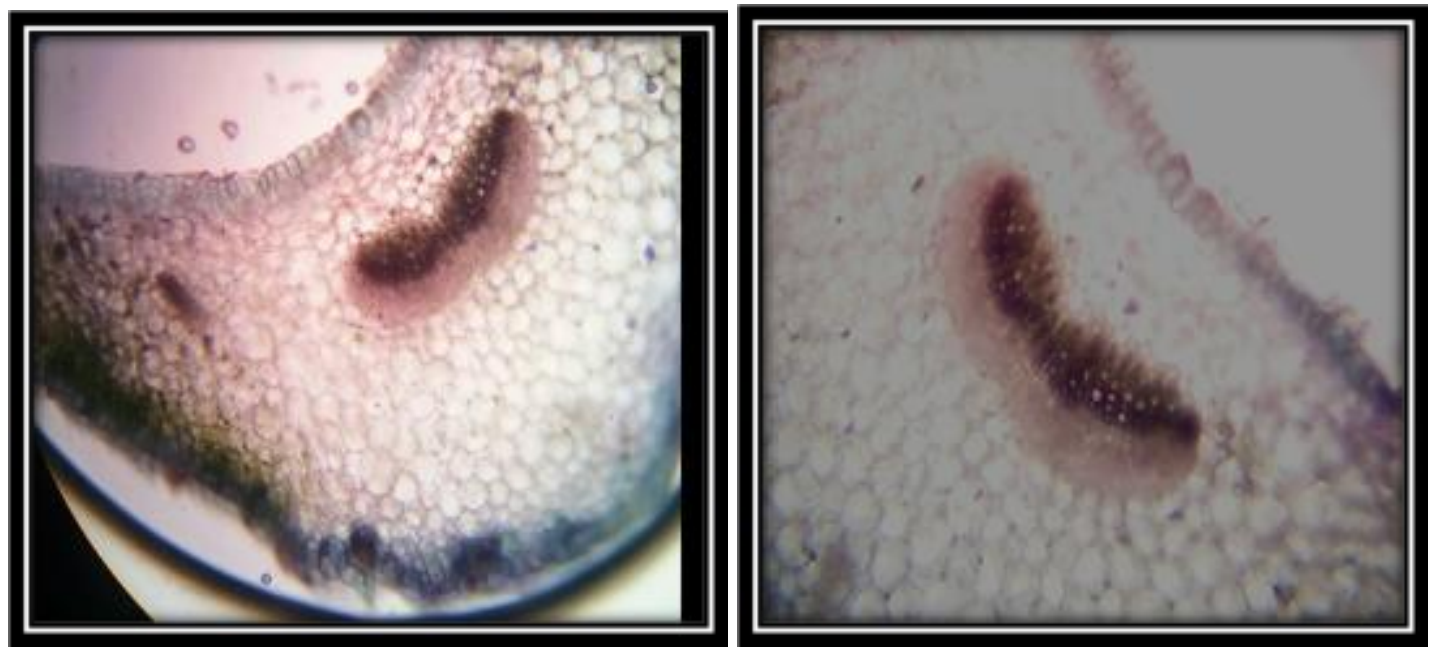

a) T.S of petiole

b) T.S of petiole with vascular bundles
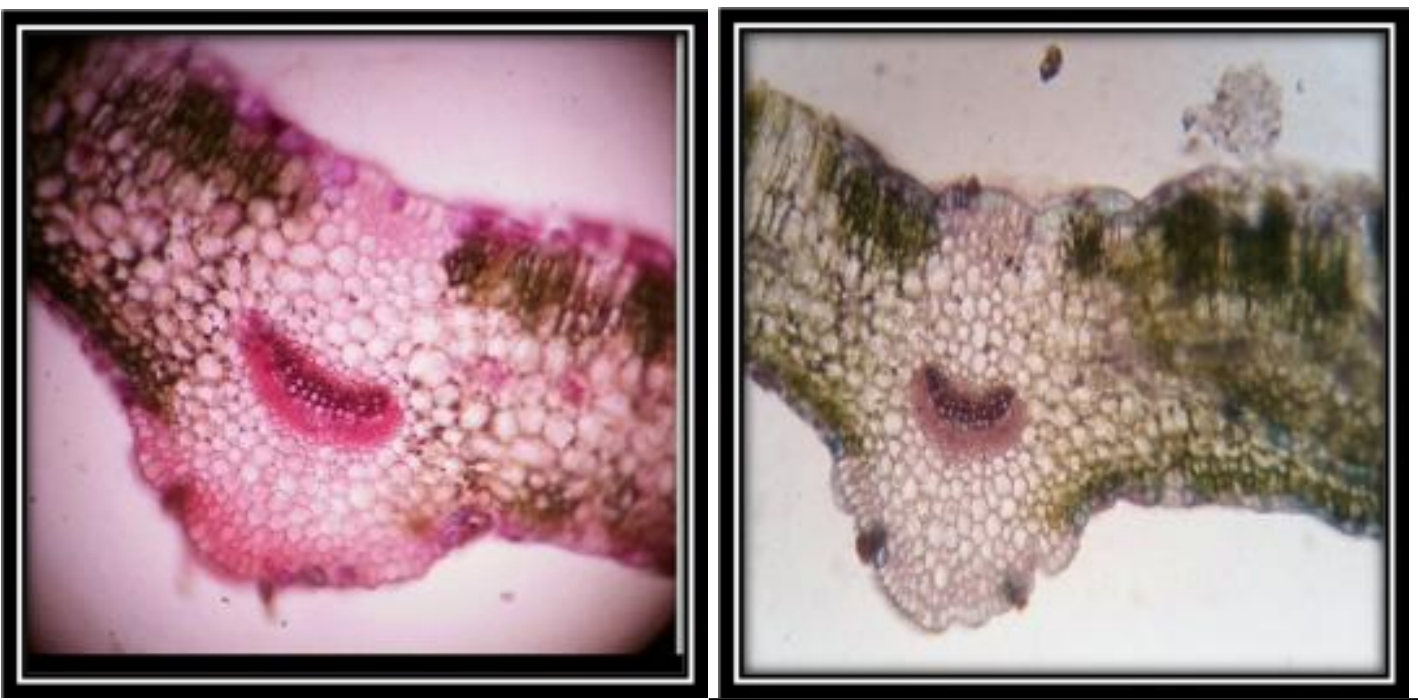

c) T.S of leaf with epidermis

d) T.S of leaf with mesophyll layer

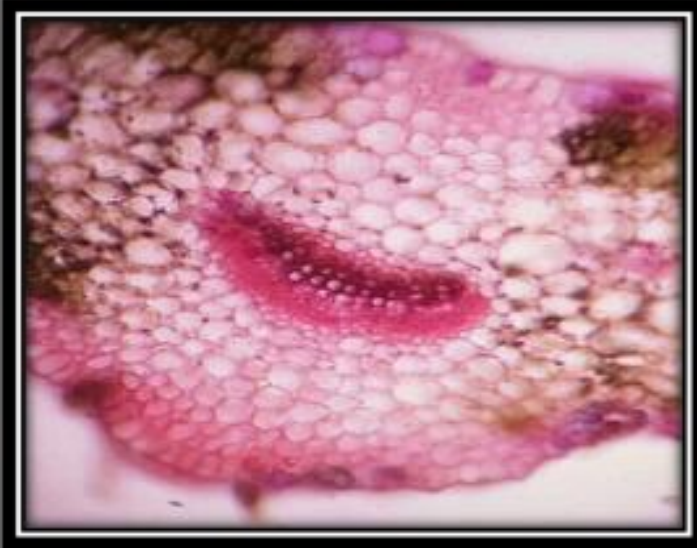

e) T.S of leaf with vascular bundles

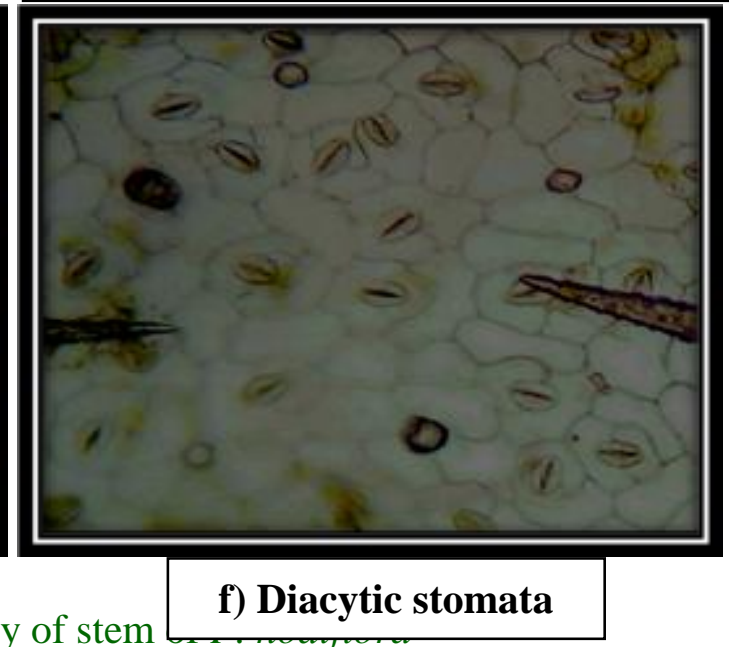




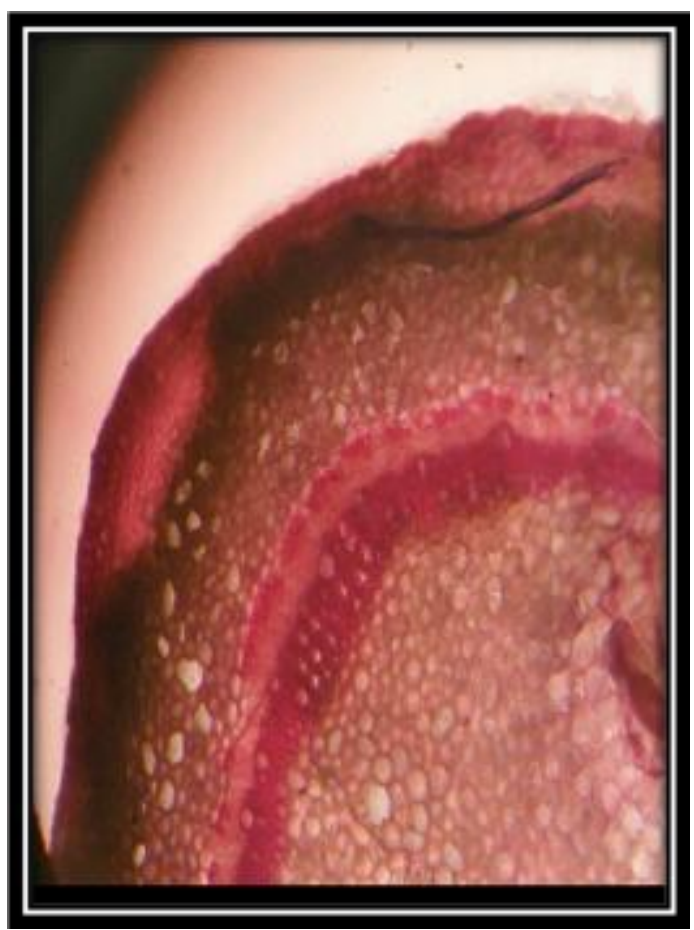

a) T.S of stem with epidermis

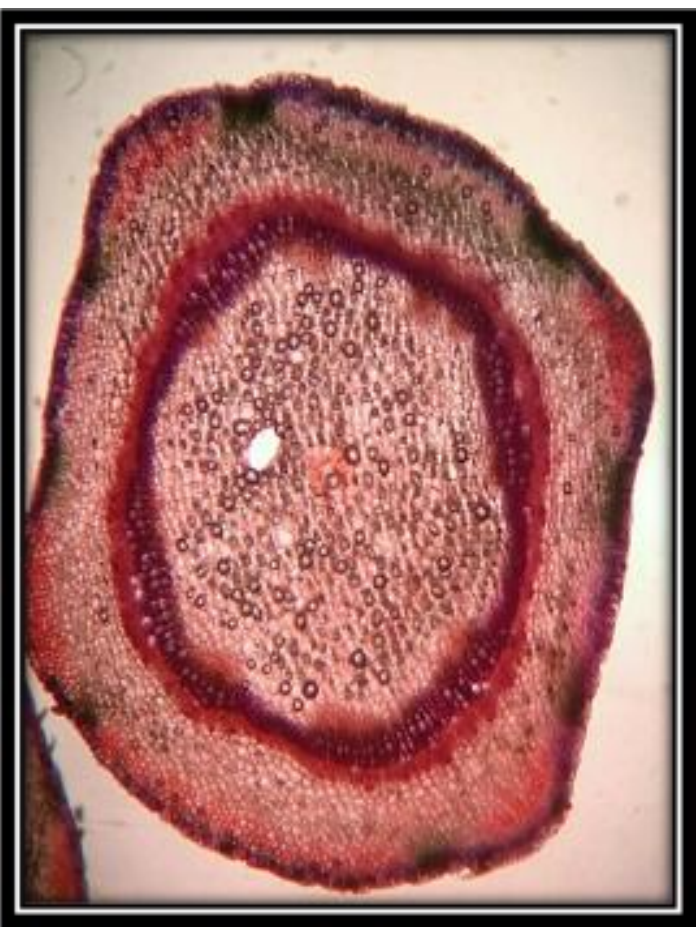

b) T.S of stem

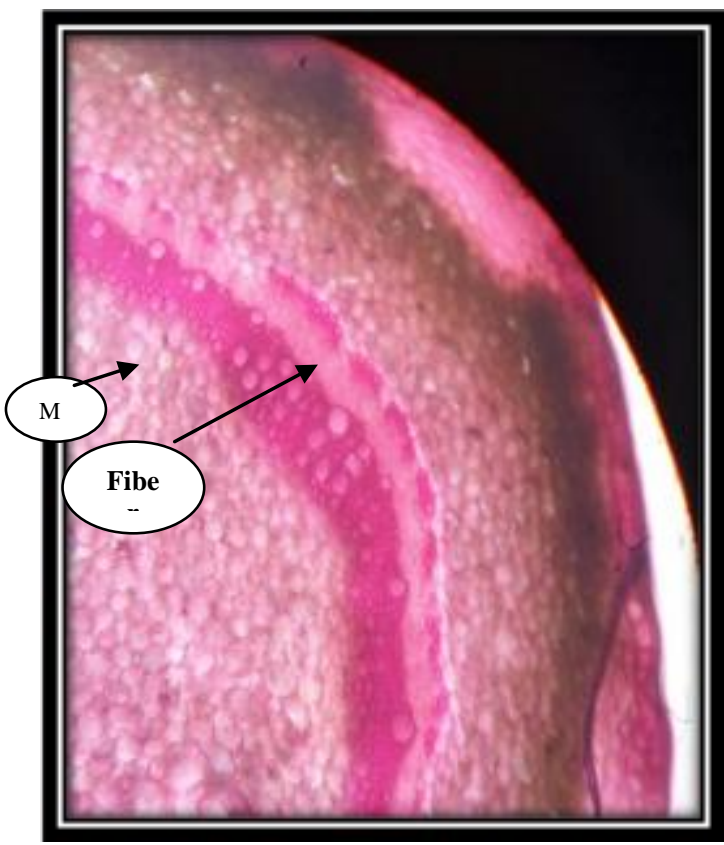

c) T.S of stem with vascular bundles

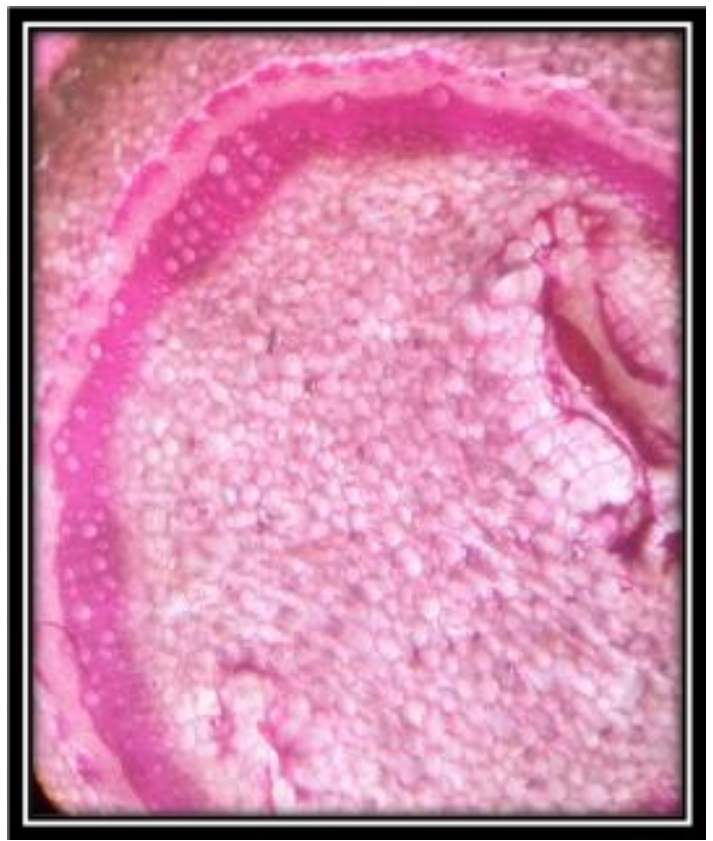

d T.S of stem with pith

Fig.6 Photomicrographs of microscopic characteristics of powder of $P$. nodiflora leaf 


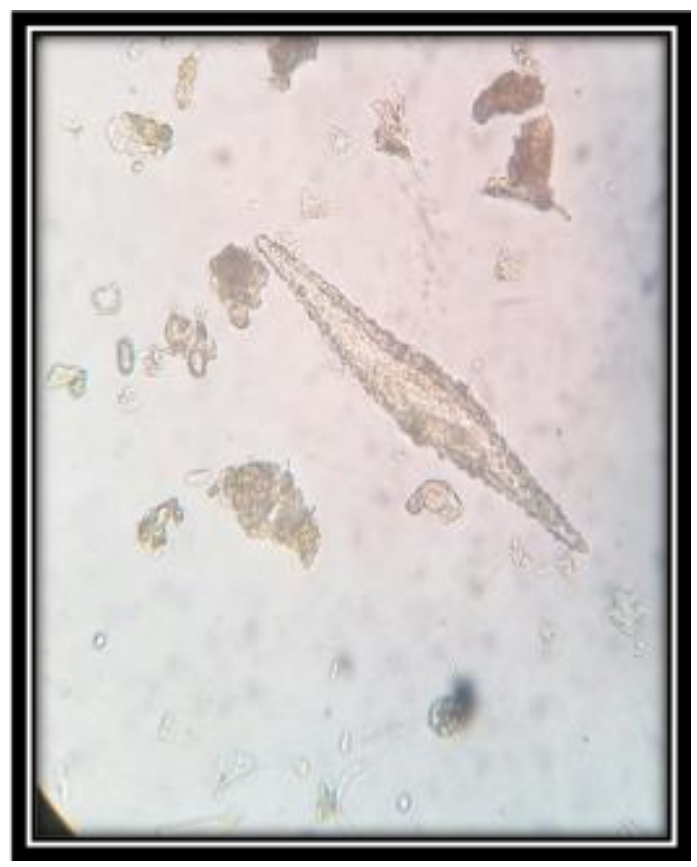

a) Unicellular trichome

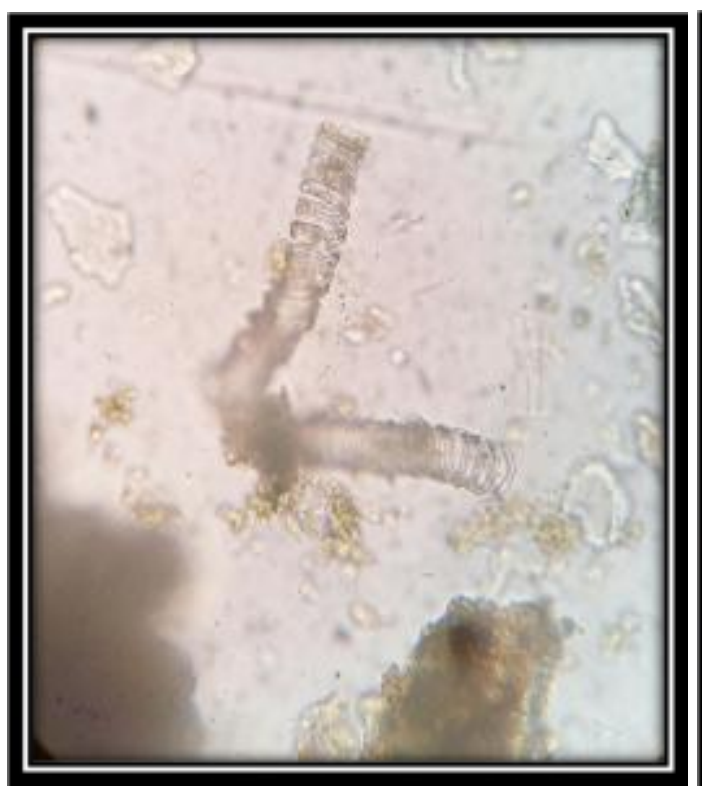

c) Annular vessels

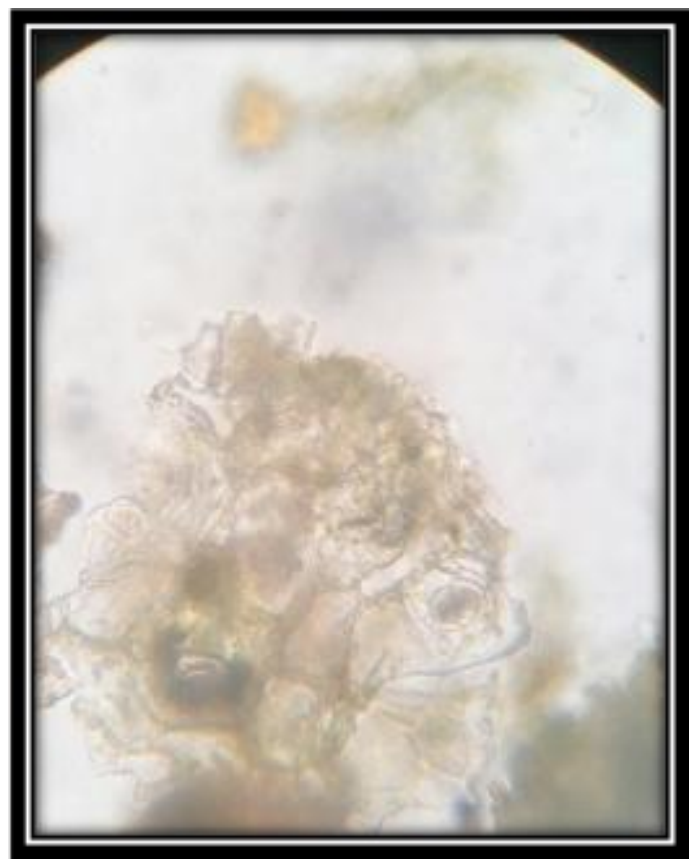

b) Diacytic stomata

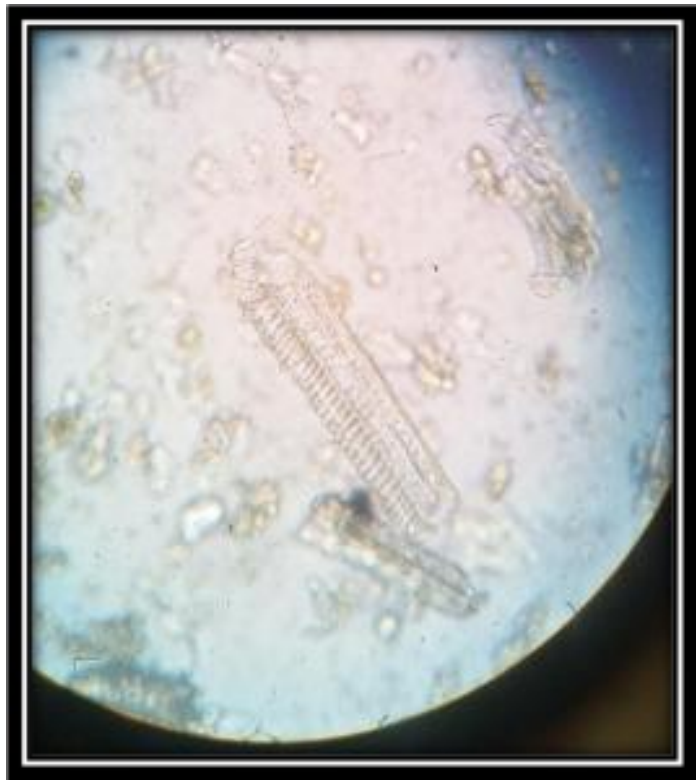

d) Spiral vessels

Fig.7 Photomicrographs of microscopic characteristics of powder of $P$. nodiflora stem 


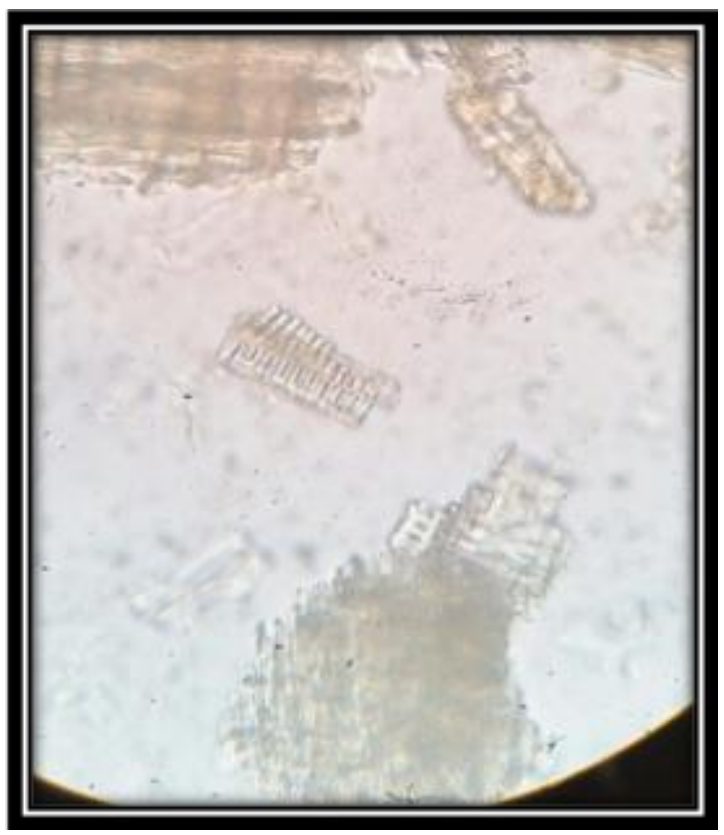

a) Border pitted vessels

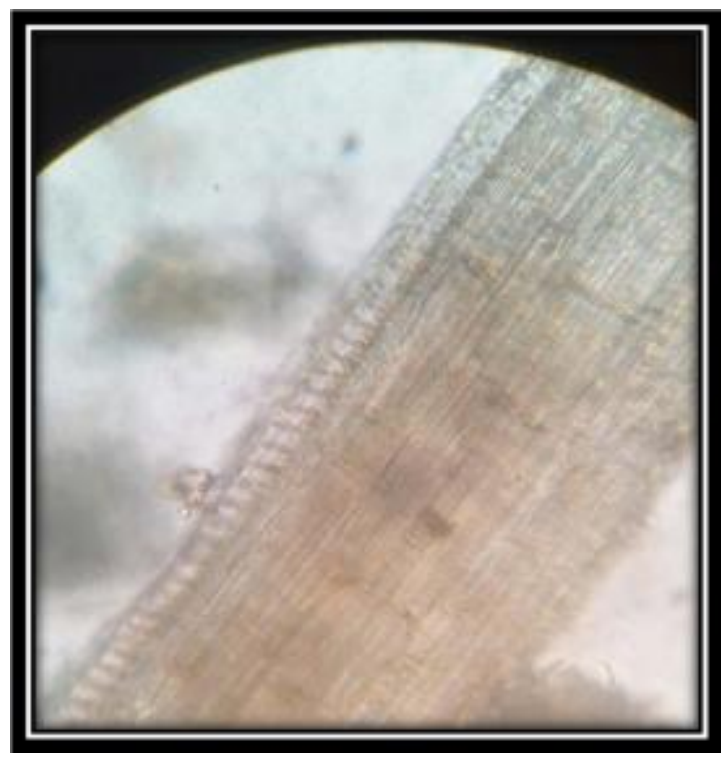

C) Spiral vessles

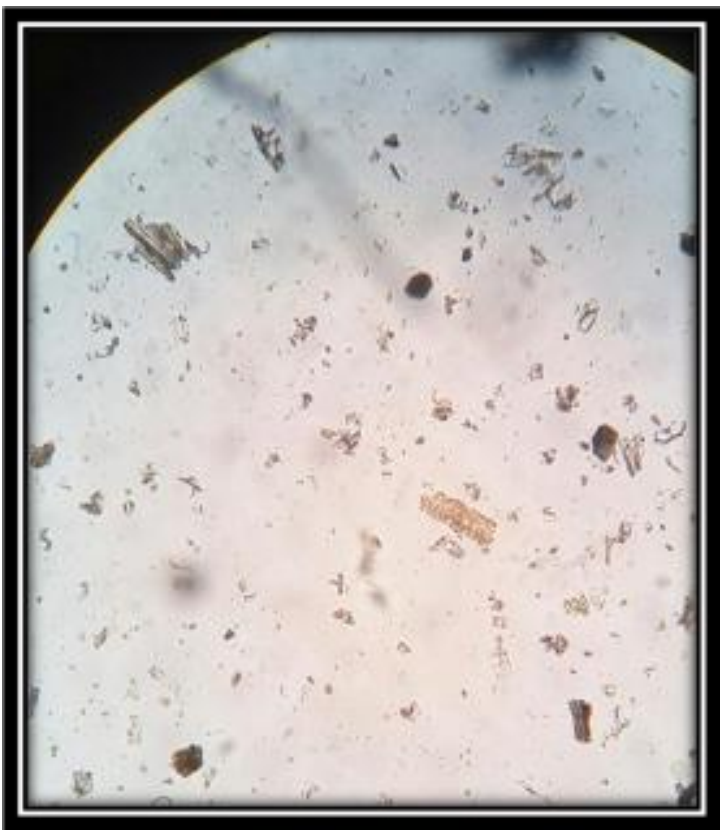

b) Annular vessels

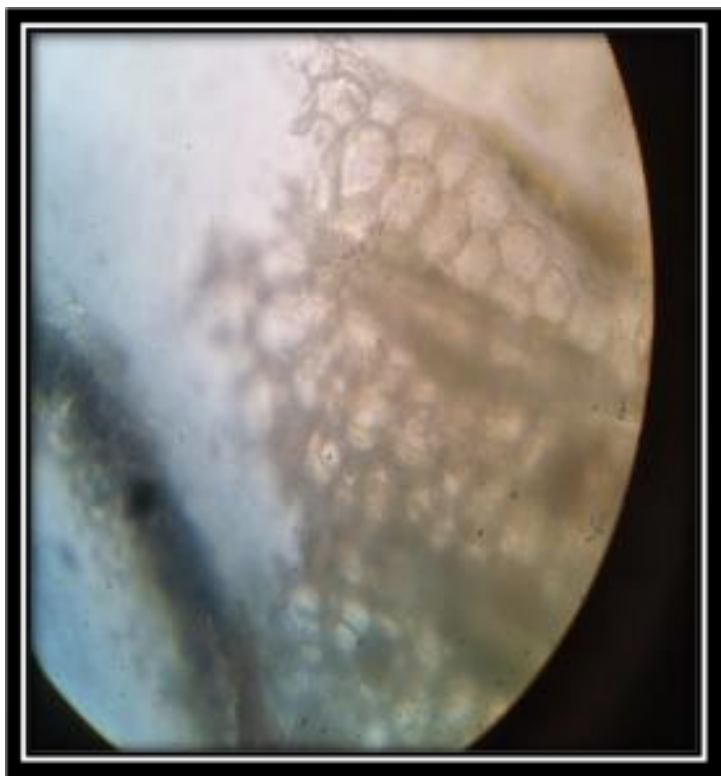

d) Parenchymatous tissue

Fig.8 Ash values of crude powder of $P$. nodiflora leaf and stem 


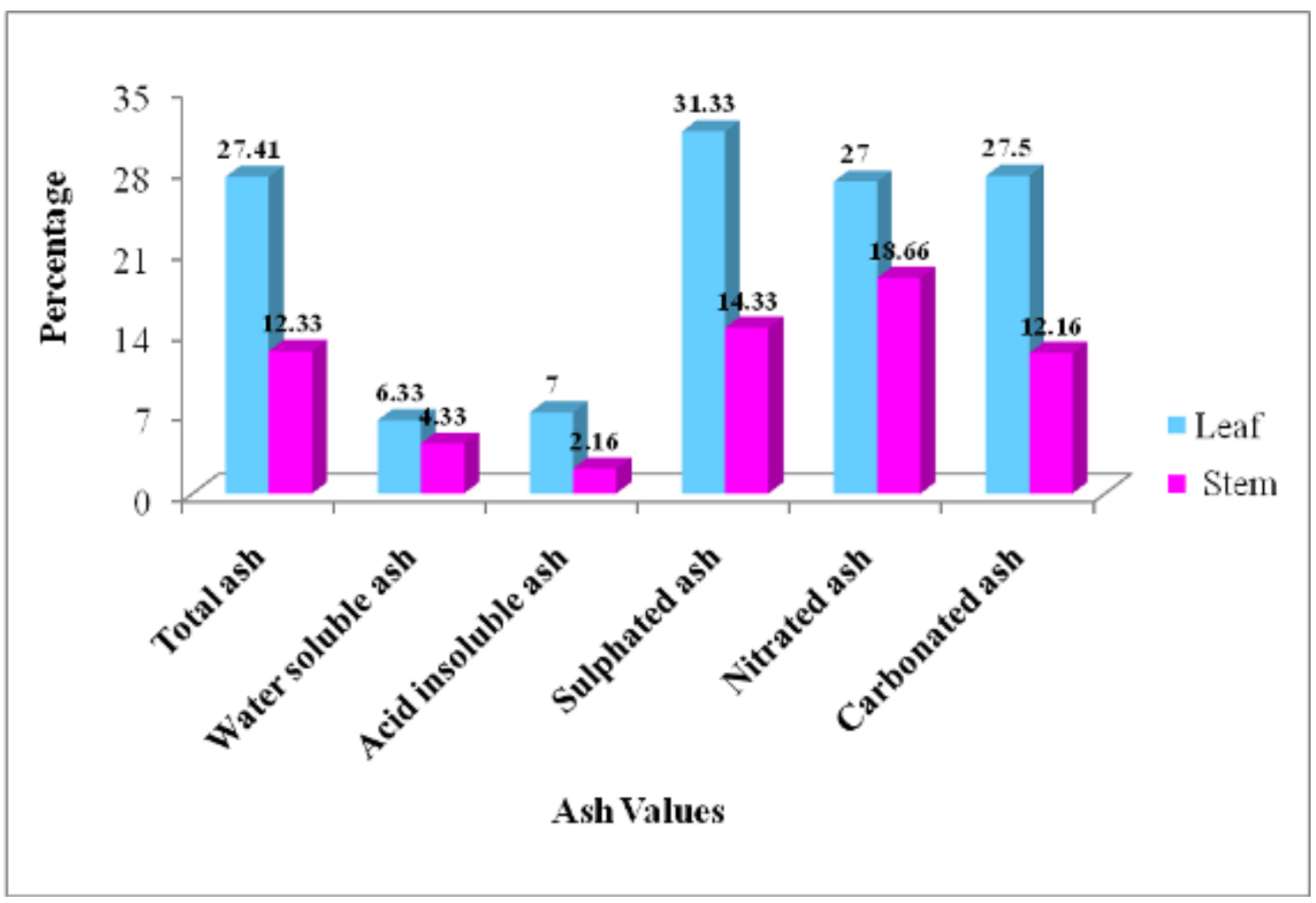

Fig.9 Extractive values of different solvent extracts of $P$. nodiflora leaf and stem

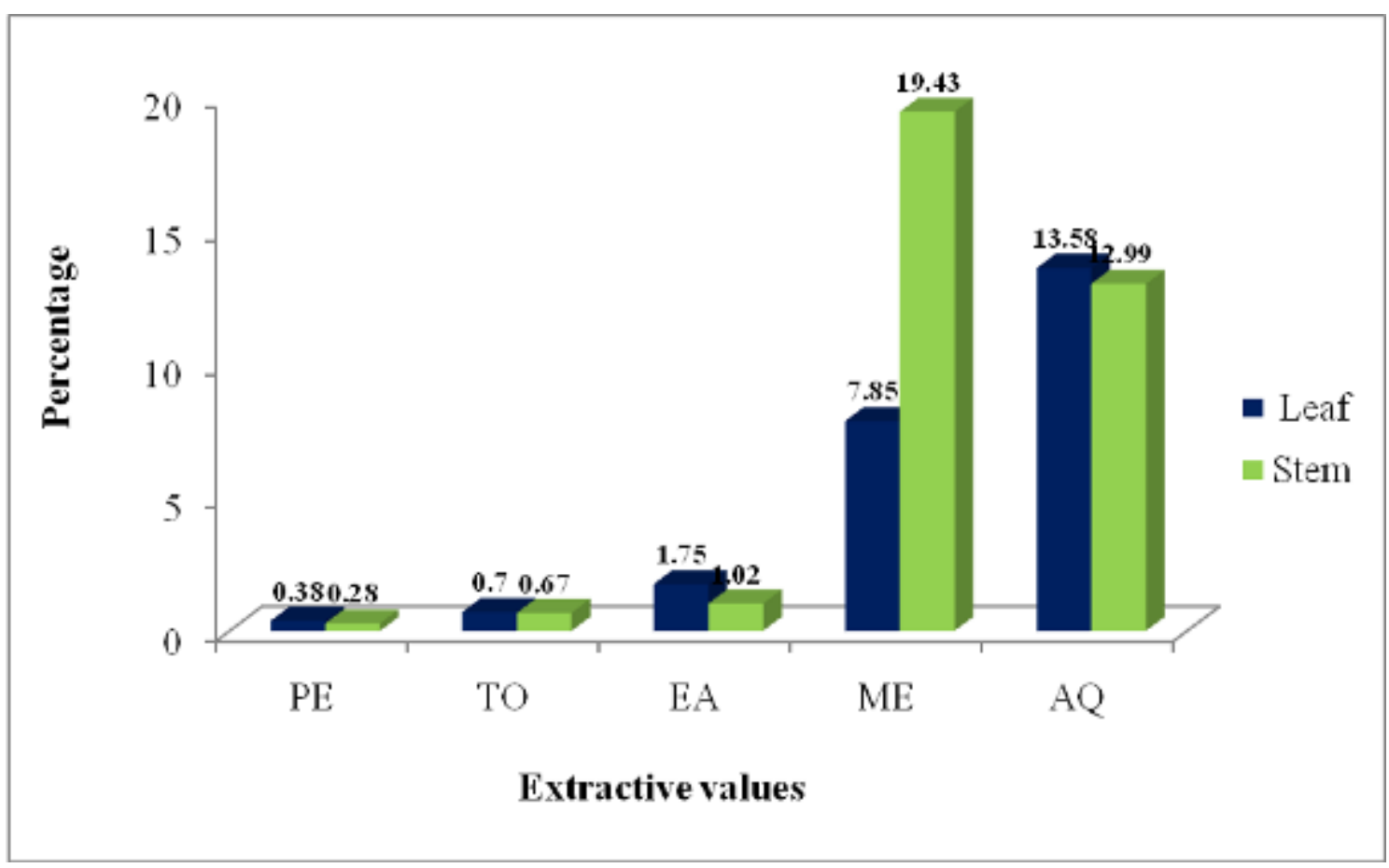

Fig.2 Quality control parameters of P. nodiflora L. Greene 


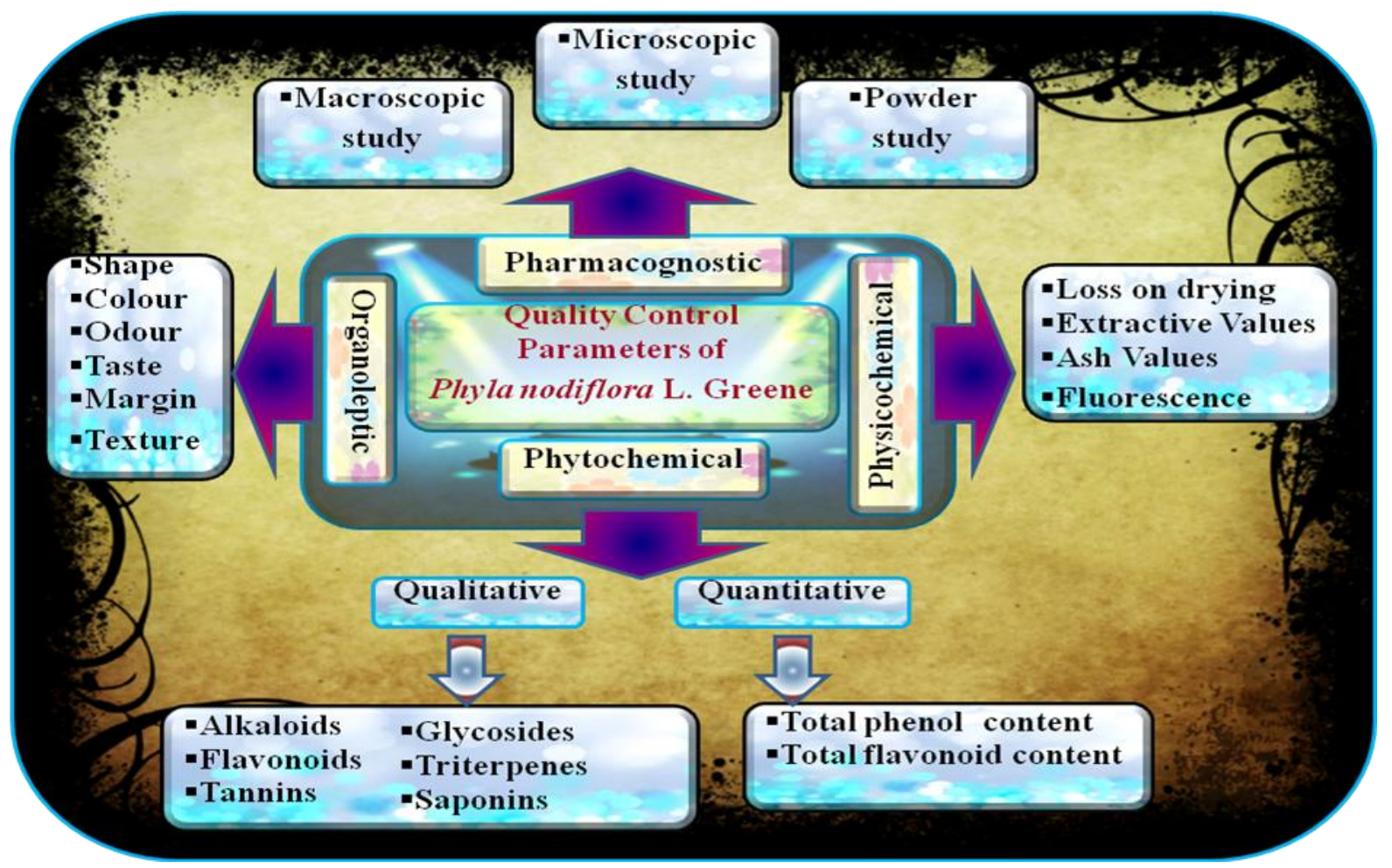

Standardization is a necessary and important aspect for the study of identity, purity and quality of crude drug sample of plant origin. There are many methods but easiest, simplest and most popular method is pharmacognostic studies (WHO, 1998). Pharmacognostic studies are reported for other plants like Madhuka indica (Moteriya et al., 2015); Hippeastrum puniceum (Kurian et al., 2017); Limonium stocksii (Kanakiya et al., 2018). Pharmacognostic studies are the first step to establish the identity and the degree of purity of the plant material under study and it will ensure the plant from being adulterated and substituted. In the present study, $P$. nodiflora leaf and stem were evaluated for their pharmacognostic, physicochemical, qualitative and quantitative phytochemical and fluorescence analysis. The macroscopic evaluation showed $P$. nodiflora leaves were green in colour, shape of leaves was spathulate, apex was retuse, base was symmetrical. The microscopic evaluation showed the leaf was dorsiventral in nature, the palisade tissue was on the upper epidermis and spongy parenchyma cells were present on the lower epidermis. Vascular bundles were towards the ventral surface. They were centrally located, conjoint, collateral; stomata were diacytic. The powder study of leaf showed unicellular trichomes, diacytic stomata, annular vessles and spiral vessles. The macroscopic evaluation showed $P$. nodiflora stem to be green in colour, herbaceous and prostate trailing. The microscopic evaluation showed the epidermis was single layered, cortex was 4-6 layered, vascular bundles were surrounded by polygonal lignified parenchyma and collenchyma cells; vascular bundles consisted of secondary phloem with sieve tubes, companion cells and phloem parenchyma. The powder study of stem showed the border pitted vessles, annular vessles, spiral vessles and phloem parenchyma. Powder study is very important for authentication of plant when it loses its morphological identity and the drug is in powder form. The diagnostic characters of each plant powder parameters will be helpful for its correct identification 
and ensure its purity. It is most simple, easy and cheapest quality control parameter. Some examples of powder study are reported by Menpara and Chanda (2014) for Pongamia pinnata L. (Family Fabacea). Sarpong et al., (2017) for Palisota hirsuta (Family Commelinaceae), Meghashree et al., (2017) for Benincasa hispida (Family Cucurbitaceae).

\section{Phytochemical analysis}

Phytochemicals present in the medicinal plants are responsible for the biological activity and it is very important to screen them. The qualitative phytochemical screening was done in crude powder of $P$. nodiflora leaf and stem. In leaf, alkaloids, flavonoids, phenols and steroids were in maximum amount while in stem alkaloids, flavonoids, saponins and phenols were present in maximum amount. Such studies are important since it gives an idea about the phytochemicals present in them and different phytochemical show curative properties to different diseases. Both leaf and stem showed presence of phenols and flavonoids and it is known that plants rich in phenols and flavonoids show good antioxidant activity and plants rich in antioxidant activity show good pharmacological or biological activity (Chanda and Dave, 2009). Similar phytochemical analysis is reported by Tang et al., (2018) for Psychotria rubra root, stem and leaves; Kanthale and Biradar (2017) for Helicteres isora fruits; Trianthema portulacastrum (Pande et al., 2018).

\section{Physicochemical analysis}

The physicochemical parameters like loss on drying, total ash, acid insoluble ash, water soluble ash, sulphated ash, nitrated ash, carbonated ash, and extractive values were determined. Loss on drying was $8 \%$ in leaf and $9 \%$ in stem. This parameter indicates the efficiency of drying process. It was less than
$10 \%$ in this plant which is quite less. It indicates that moisture content is less and it will not encourage the growth of bacteria and fungi (Pande et al., 2018). Loss on drying for Chaetomorpha antennina was 7\% (Dhanki et al., 2018), 9\% for Homalium ceylanicum (Acharya et al., 2018). The ash values were more in leaf than in stem. The ash values measures the amount of organic and inorganic material present in the plant sample (Shrestha et al., 2014; Yazdinezhad et al., 2016). In $P$. nodiflora, inorganic compounds were present more in leaf than in stem; some of the ash was slightly high as also reported for aerial parts of Colebrookea oppositifolia by Ishtiaq et al., (2016).

Extractive values in different solvents give the idea about the nature of secondary metabolites present in the crude drug. In both leaf and stem, the maximum extractive value was in ME solvent and minimum in PE solvent. The water soluble extractive value was also more in both leaf and stem. The results indicate that polar compounds were more than non polar compounds. The non polar compounds were present in trace amount since PE and TO solvent had minimum extractive value both in leaf and stem. Extractive values give an idea about the nature of phytoconstituents present in the crude drug or plant sample. They are also indicative of adulteration so purity of the drug can be checked (Foudah et al., 2015; Netala et al., 2015; Rokad et al., 2018).

\section{Fluorescence analysis}

In the present study crude powder of $P$. nodiflora leaf and stem was treated with various reagents which showed characteristic fluorescence at $254 \mathrm{~nm}$ and $366 \mathrm{~nm}$ wave length. Similar fluorescence analysis is reported for Terminalia arjuna (Desai and Chanda, 2014) and for Zanthoxylum armatum (Barkatullah et al., 2017). Fluorescence analysis is a necessary parameter for the first 
line standardization of the crude drugs. Light reach in short wave length is very active in producing fluorescence and for this reason ultraviolet right is very active in producing fluorescence in many substances which are not visibly fluorescent in visible light.

In conclusion, the quality control parameters i.e. the physicochemical, phytochemical, macroscopic and microscopic characteristic along with the powder studies of leaf and stem of $P$. nodiflora done in the present work are the diagnostic features of $P$. nodiflora. They are useful in maintaining the identity, efficacy and safety of this medicinally useful plant. The phytochemical studies and extractive values will give an idea regarding its use for a particular pharmacological activity.

\section{Acknowledgement}

The authors thank Department of Biosciences (UGC-CAS) for providing excellent research facilities.

\section{References}

Abbasi AM, Khan MA, Ahmad M, Zafar M, Jahan S, Sultana S (2010). Ethnopharmacological application of medicinal plants to cure skin diseases and in folk cosmetics among the tribal communities of North-West Frontier Province, Pakistan. Journal of Ethnopharmacology. 128(2): 322-335.

Acharya R, Jani S, Chinappa R, Shukla V (2018). Pharmacognostical and phytochemical analysis on leaves of Homalium ceylanicum (Gardn.) Benth. Pharmacognosy Journal. 10(2):272-277.

Ahmed F, Selim MS, Das AK, Choudhuri MS (2004). Anti-inflammatory and antinociceptive activities of Lippia nodiflora linn. Die Pharmazie 59(4): 329-330.

Arumugam S, Kavimani S, Kadalmani BS, Ahmed ABA, Akbarsha MA, Rao MV (2008). Antidiabetic activity of leaf and callus extract of Aegle marmelos in rabbit. Science Asia. 34:317-321.
Balamurugan R, Duraipandiya V, Ignacimuthu $\mathrm{S}$ (2011). Antidiabetic activity of $\gamma$-sitosterol isolated from Lippia nodiflora $\mathrm{L}$. in streptozotocin induced diabetic in rats. European Journal of Pharmacology Research. 667(1-3): 410-418.

Balkan IA, Goren AC, Kirmizibekmez H, Yesilada E (2018). Evaluation of the in vitro antiinflammatory activity of Nerium oleander L. flower extracts and activity guided isolation of the active constituents. Records of Natural Products. 12(2):128-141.

Barkatullah IM, Muhammad N, Khan A, Khan SA, Zafar S, Jan S, Riaz N, Ullah Z, Farooq U, Hussain J (2017). Pharmacognostic and phytochemical studies of Zanthoxylum armatum DC. Pakistan Journal of Pharmaceutical Sciences. 30(2): 429-438.

Chanda S (2014). Importance of pharmacognostic study of medicinal plants: an overview. Journal of Pharmacognosy and Phytochemistry. 2 (5): 69-73.

Chanda S and Dave R (2009). Review: In vitro models for antioxidant activity evaluation and some medicinal plants possessing antioxidant properties: an overview. African Journal of Microbiology Research. 3:981-996.

Chen DQ, Feng YL, Tian T, Chen H, Yin L, Zhao YY, Lin RC (2014). Diuretic and antidiuretic activity fractions of Alismatis rhizoma. Journal of Ethnopharmacology. 157: 114-118.

Desai D and Chanda S (2014). Pharmacognostic study and physicochemical analysis of leaves of Terminalia arjuna. Pharmacognosy Journal. 6(6):15-19.

Dhanki A, Pande J, Donga S, Chanda S (2018). Pharmacognostic standardization of Chaetomorpha antennina and Ulva lactuca, green seaweeds from Gujarat coast. Journal of Pharmacognosy and Phytochemistry. (In Press).

Donga S, Moteriya P, Chanda S (2017a). Evaluation of antimicrobial and synergistic antimicrobial properties of Pterocarpus santalinus. Asian Journal of Pharmaceutical and Clinical Research. 10(11):204-209.

Donga S, Pande J, Chanda S (2017b) Evaluation of phytochemical and antioxidant potential of Pterocarpus santalinus Linn. f. LAP LAMBERT Academic Publishing GmbH \& Co. KG, Heinrich-Bocking-Straße 6-8, 66121 Saarbrucken, Germany. 
Durairaj AK, Vaiyapuri TS, Mazumdar UK, Gupta M (2007). Antimicrobial and lipid peroxidase scavenging activity of Lippia nodiflora (Verbenaceae). Pharmacology Online. 3: 177189.

Edeoga HO, Okwu DE, Mbaebie BO (2005). Phytochemical constituent of some Nigerian medicinal plants. African Journal of Biotechnology. 4(7):685-688.

Foudah AI, Alam A, Soliman GA, Salkini MA, Ahmed EOI, Yusufoglu HS (2015). Pharmacognostical, antioxidant and antimicrobial studies of aerial part of Pulicaria crispa (Family: Asteraceae). Bulletin of Environment, Pharmacology and Life Sciences. 4(12):19-27.

Gurib-Fakim A (2006). Medicinal plants- traditions of yesterday and drugs of tomorrow. Molecular Aspects of Medicine. 27(1):1-93.

Harborne AJ (1998). Phytochemical methods a guide to modern techniques of plant analysis. Springer Science and Business Media.

Hussain, F, Shahid, M, Javed, K. (2015). Antioxidant, antiglycation and alpha amylase inhibitory activities of Cassia abrus seeds. Current Science, Prospectives. 2(1): 5-9.

Ishtiaq S, Meo MB, Afridi MSK, Akbar S, Rasool S (2016). Pharmacognostic studies of aerial parts of Colebrookea oppositifolia Sm. Annals of Phytomedicine. 5(2); 161-167.

Kanakiya A, Padalia H, Pande J, Chanda S (2018). Physicochemical, phytochemical and pharmacognostic study of Limonium stocksii, an halophyte from Gujarat. Journal of Phytopharmacology. (In Press).

Kanthale PR and Biradar S (2017). Pharmacognostic study of Helicteres isora L. Pharmaceutical and Biological Evaluations. 4(1): 47-51.

Khandelwal KR (2008). Practical Pharmacognosy 19th edn. Pune, India. Nirali Prakashan. 49-70.

Kokaski CJ, Kokaski RJ, Slama FJ (1958). Fluoresecence of powdered vegetable drug under ultraviolet radiation. Journal of the American Pharmacists Association. 47(10): 715-718.

Kumar PPNV, Pammi SVN, Kollu P, Satyanararayana KVV, Shameem U (2014). Green synthesis and characterization of silver nanoparticles using Boerhaavia diffusa plant extract and their antibacterial activity. Industrial Crops and Products. 52: 562-566.

Kurian P, Kuriakose BB, Vijayakumar B (2017). Pharmacognostic and physicochemical evaluation of Hippeastrum puniceum (lam.) voss leaves. American Journal of Biological and Pharmaceutical Research. 4 (2): 42-45.

Malathi R, Cholarajan A, Karpagam K, Jaya KR, Muthukumaran P (2011). Antimicrobial studies on selected medicinal plants (Coleus amboinicus, Phyla nodiflora and Vitex negundo). Asian Journal of Pharmaceutical Technology and Innovation. 1(2):53-55.

Meghashree BM, Shantha TR, Venkateshwarlu G, Bhat S (2017). Comparative pharmacognostical and histochemical studies on Benincasa Hispida (Thunb.) CogN.- fruit and seed. International Journal of Herbal Medicine. 5(4): 17-24.

Menpara D and Chanda S (2014) Phytochemical and pharmacognostic evaluation of leaves of Pongamia pinnata L. (Fabaceae). Pharmacognosy Communications. 4(2):3-7.

Moteriya P, Padalia H, Rathod T, Desai D, Chanda S (2015). Pharmacognostic standardization of Madhuka indica leaf and stem, an important medicinal plant. International Journal of Pharmaceutical Sciences and Research. 6 (2):705-711.

Muthaiyan AR, Periasamy M, Velliyur KG (2015). Hepatoprotective activity of ethanolic extract of Alysicarpus vaginalis against nitrobenzene induced hepatic damage in rats. South Indian Journal of Biological Sciences. 1(2):60-65.

Muthkar HM, Ansari SH, Bhat ZA, Naved T, Singh $P$ (2006). Antidiabetic activity of an ethanol extract obtained from the stem bark of Psidium guajava (Myrataceae). Pharmazie. 8:725-727.

Nasri H and Shirzad H (2013). Toxicity and saftety of medicinal plants. Journal of Herbmed Pharmacology. 2(2):21-22.

Netala S, Penmetsa R, Nakka S, Polisetty BL (2015). Pharmacognostic study of Callistemon Citrinus L. bark. International Journal of Pharmacy and Pharmaceutical Sciences. 7(1): 427-430.

Pande J, Kanakiya A, Padalia H, Chanda S (2018). Physicochemical, phytochemical and pharmacognostic evaluation of a halophytic plant, Trianthema portulacastrum L. International Journal of Current Microbiology and Applied Science. (In Press).

Pirzada AJ, Iqbal P, Shaikh W, Kazi TG, Ghani KV (2005). Studies on the elemental composition and antifungal activity of medicinal plant $L$. nodiflora against skin fungi. Journal of 
Pakistan Association of Dermatology. 15(2):113-118.

Rakholiya K, Kaneria M, Chanda S (2014a). Inhibition of microbial pathogens using fruit and vegetable peel extracts. International Journal of Food Science and Nutrition. 65(6): 733-739.

Rakholiya K, Kaneria M, Chanda S (2014b). Antimicrobial and antioxidant potency of Mangifera indica L. leaf LAP LAMBERT Academic Publishing GmbH \& Co. KG, Heinrich-Bocking-Straße 6-8, 66121 Saarbrucken, Germany.

Rokad N, Pande J, Chanda S (2018) Pharmacognostic and phytochemical studies of Ipomoea pes-caprae, an halophyte from Gujarat. Journal of Pharmacognosy and Phytochemistry. 7(1): 11-18.

Sarpong FM, Armah FA, Amponsah IK, Atchoglo PK, Ampofo EK, Nortey NND (2017). Pharmacognostic and physico-chemical investigation of Palisota hirsuta (K. Schum) (Commelinaceae). Journal of Pharmacognosy and Phytochemistry. 6(1): 187-191.

Shrestha S, Kaushik VS, Eshwarappa RS, Subaramaihha SR, Ramanna LM, Lakkappa DB (2014). Pharmacognostic studies of insect gall of Quercus infectoria Olivier (Fagaceae). Asian Pacific Journal of Tropical Biomedicine. 4(1): 35-39.
Shu YZ (1998). Recent natural products based drug development: a pharmaceutical industry perspective. Journal of Natural Products. 61:1053-1071.

Tang G, Lin X, Lai X, Gong X, Ji S (2018). Pharmacognostic studies of Psychotria rubra (Lour.) poir. Pharmacognosy Journal. 10(2); 249-255.

Thirapathy KP, Tulshkas A, Vijaya C (2011). Neuropharmacological activity of Lippia nodiflora Linn. Pharmacognosy Research. 3(3):194-200.

Tyler V, Brady L, Robber J (1977). Pharmacognosy, Varghese Company, India, 103-141.

Verma S and Singh SP (2008).Current and future status of herbal medicines. Veterinary World. 1(11):347-350.

WHO (1998). Quality control methods for medicinal plant materials. World Health Organization. Geneva.

Yazdinezhad A, Ramezanloo N, Mozaffari SH (2016). Pharmacognostic and phytochemical investigation of Heracleum persicum Desf. ex Fischer. Research Journal of Pharmacognosy. 3(2): 17-24.

Zhen J, Villani TS, Guo Y, Qi Y, Chin K, Pan MH, Ho CI, Simon JE, Wu Q (2016). Photochemistry, antioxidant capacity, total phenolic content and anti-inflammatory activity of Hibiscus sabdrifa leaves. Food Chemistry. 190:673-680.

\section{How to cite this article:}

Bhoomi Trivedi, Savan Donga, Jyoti Pande and Sumitra Chanda. 2018. Comparison of Quality Control Parameters of Leaf and Stem of Phyla nodiflora L. Greene (Verbenaceae). Int.J.Curr.Microbiol.App.Sci. 7(05): 2808-2828. doi: https://doi.org/10.20546/ijcmas.2018.705.327 